\title{
Molecular Detection of Begomoviruses Infecting Some Vegetable Crops in Saudi Arabia
}

\author{
Khalid Alhudaib \\ King Faisal University, Alhasa, Eastrn, Saudi Arabia \\ kalhudaib@kfu.edu.sa
}

\begin{abstract}
Begomoviruses have a huge impact on crop production worldwide. Investigations of begomviruses in four vegetable crops namely cucumber, squash, tomato, and watermelon were conducted by visual symptoms and molecular analysis using PCR with universal primers for begomoviruses. Obtained sequencing results of the core Coat Protein confirmed the presence of three already reported begomoviral species. TYLCV was detected on tomato samples exhibiting leaf curling and yellowing. Squash and greenhouse-grown cucumber plants were infected with the Oman strain TYLCV-OM. Watermelon chlorotic stunt virus (WmCSV) isolates were detected in watermelon and greenhouse cucumbers. The begomoviral species ToLCPMV shared $99 \%$ identity with the Iranian isolates that are known to be very destructive. Integrated pest management should be implemented against whitefly (Bemisia tabaci) to prevent the spread of begomoviruses on vegetable crops.

Keywords. Begomoviruses, cucumber, squash, tomatoes, watermelon, PCR.
\end{abstract}

\section{Introduction}

Weedy plants are widely dispersed and persist Viral diseases caused by the Begomoviruses (family Geminiviridae) remain the most serious threat of global vegetable production. In Saudi Arabia, the first begomoviruse was detected in the eastern province, which caused mosaic symptoms on tomato plants (Talhouk, 1957). Since then, begomoviral diseases were reported on different crops in new geographical regions from Saudi Arabia. Symptoms appeared as dwarfism, leaves deformation, mosaic, vein yellowing, and stunting. Among those viruses, Okra leaf curl virus (OLCV) (Ghanem et al. 2003), Tomato yellow leaf curl virus (TYLCV) has been reported in Alhasa region on tomato and cultivated cucumber plants in Jeddah, Saudi Arabia (Alhudiab et al,. 2014, Sohrab et al,. 2017) and Tomato leaf curl Sudan virus
(ToLCSDV) was detected on squash ( Sohrab, 2017), Watermelon chlorotic stunt virus (WmCSV) infection was reported on watermelon (Al-Saleh et al., 2014; Soliman et al., 2018).

There are 322 species within the genus Begomovirus detected by the International Committee on Taxonomy of Viruses (ICTV) in 2017 (Zerbini et al., 2017). So that, this genus is considered the largest genus in plant viruses, which contains one or two of circular single strand of DNA (ssDNA) (Zerbini et al., 2017). The first group containing Bipartite (DNA-A and DNA-B), which are prevalent in the New World, such as USA, Mexico and South America, while the monopartite group spreads in the Old world (OW), such as those countries in the continents of Asia, Africa, Europe and Australia. Monopartite begomoviruses contain particles associated 
with the additional molecules called alphasatellites and betasatellites. These associated molecules are related to pathogenesis, symptom modulation and also act as silencing suppressors (Zhou, 2013). Despite the large number of viruses that have been detected around the world, all viruses in Begomvirus genus are transmitted by whitefly (Bemisia tabaci) biotype B (Gilbertson et al., 2015) which is the dominant type in Saudi Arabia (Alhudaib et al., 2014).

As the incidence of Begomoviruses increases in most areas of the Kingdom, with the increase in susceptible hosts, new strains are likely to be detected, further studies should be conducted to provide information on the various viruses of this genus. This study aimed to determine the status of begomviruses infecting important vegetable crops e.g. tomato, cucumber, squash and watermelon using universal primers and characterization of these viruses via sequence of coat protein genes from detected viruses in order to benefit from these results in reducing the spread of these viruses.

\section{Material and Methods}

\subsection{Field Visits and Collection of Samples}

Vegetable fields were visited during the vegetable growing season in spring 2017-18 and leaf samples were collected from the symptomatic tomato, squash, cucumber and watermelon plants showing virus-like symptoms such as dwarf, wrinkle, veins yellowing, and mosaic. Ten samples from cucumber plants exhibited symptoms were selected from two greenhouses while tomatoes, squash and watermelon samples were collected from open fields in Alhasa area in the Eastern province where ten samples were collected with viral symptoms from tomatoes, squash and seven samples were collected from watermelon.

\subsection{Extraction of Genomic DNA}

Nucleic acid extractions and PCR amplifications were done in the Pests and plant diseases unit, College of Agricultural and Food Science, King Faisal University. Total DNA was extracted according to the method described by Doyle (1987) with some modification. About $100 \mathrm{mg}$ leaf tissue was grinded with sand in 700 ul of CTAB buffer (2\% CTAB, $1.42 \mathrm{M} \mathrm{NaCl}, 20 \mathrm{mM}$ EDTA and $100 \mathrm{mM}$ Tris $\mathrm{pH} 8,2 \%$ Polyvinylpyrolidone (PVP40) and 1.5\% $\beta$ - mercapto ethanol ) then the mix was vortexed and incubated for $30 \mathrm{~min}$ at $65{ }^{\circ} \mathrm{C}$. the mixture was centrifugest for 1 min at $10,000 \mathrm{rpm}$ then $500 \mathrm{ul}$ was transferred to a new $1.5 \mathrm{ml}$ tube then $500 \mathrm{ul}$ of chlorophorm was added and mixed by vigorously vortexing. The mix was spun for 10 min at $10.000 \mathrm{rpm}$ then the supernatant was removed to a new $1.5 \mathrm{ml}$ tube and the DNA was precipitated by adding $300 \mathrm{ul}$ cold isopropanol. The mix was centrifuged for 10 min at $13000 \mathrm{rpm}$ then the precipitated DNA pellet was washed with $70 \%$ cold ethanol two times. Then the pellet was air-dried and dissolved in $50 \mathrm{ul}$ free nuclease water.

\subsection{PCR Amplification, Agarose Gel Electrophoresis and Sequencing}

The PCR amplification of the begomovirus was carried out using the degenerate primer pair, AV494 (5'GCCYATRTAYAGRAAGCCMAG-3') and AC1048 (5'-GGRTTDGARGCATGHGTACATG3') (Wyatt and Brown, 1996)). The PCR reaction was done in a $25 \mu \mathrm{l}$ reaction containing $1 \mu \mathrm{l}$ of the DNA extract ( $\sim 40 \mathrm{ng}$ of genomic DNA), $2 \mathrm{mM} \mathrm{MgCl} 2,2.5$ of 10x PCR buffer, $1.5 \mu \mathrm{L}$ of $10 \mu \mathrm{M}$ of each primer, $2.5 \mu \mathrm{l}$ of $10 \mathrm{mM}$ dNTPs, $0.3 \mu \mathrm{l}$ of $5 \mathrm{U}$ Taq DNA Polymerase (Biomatik, USA) to a final volume of $25 \mu \mathrm{L}$ with Nuclease-free water. PCR was conducted in the ESCO Swift Maxi Thermal Cycler. The PCR conditions were as follow: 
Initial denaturation at $95^{\circ} \mathrm{C}$ for 2 min and 30 cycles of denaturation at $95^{\circ} \mathrm{C}$ for $1 \mathrm{~min}$, primer annealing at $58^{\circ} \mathrm{C}$ for $1 \mathrm{~min}$, extension at $72^{\circ} \mathrm{C}$ for $1 \mathrm{~min}$ follow by a final extension cycle at $72^{\circ} \mathrm{C}$ for $10 \mathrm{~min}$. The PCR products were resolved to be analyzed on an agarose gel electrophoresis using TBE buffer.

The confirmed PCR products were purified using PCR purification kit (Qiagen) and the purified PCR products were sequenced by Macrogen Inc., (Korea) in both directions using AV494/ AC1048 primer pair.

\subsection{Sequence Comparisons and Phylogenetic Analysis}

The nucleotide sequences of the core coat protein $(\mathrm{CP})$ were initially analyzed using Blastn in online database (http:www.ncbi.nlm.nih.gov) with the already submitted sequences. The top hits were downloaded and used to compare the sequences obtained in this study. The pairwise nucleotide sequence comparison was carried out using Muscle algorithm available in species demarcation tool (SDT) (Muhire et al., 2014). The evolutionary distances were computed using the Kimura 2-parameter method (Kimura, 1980) and evolutionary analyses were conducted in MEGA7 software (Kumar et al., 2016 ).

\section{Results and Discussion}

Plants showing different viral like symptoms including leaf curling, yellowing, distortion, and stunting were collected. The symptomatic plants were suspected to be positive for the presence of begomovirus infection (Fig. 1).

For further confirmation PCR analysis were carried out using degenerate primers (AC1048/AV494), which are universally designed to amplify the core CP gene of the begomoviruses. The PCR amplicons when electrophoresed on the agarose gel showed that cucumber $(10 / 10)$, squash $(10 / 10)$, tomato $(09 / 10)$ and watermelon $(04 / 07)$ plants were positive and produced the expected $\sim 550 \mathrm{bp}$ amplification (Fig. 2).

The bands were purified from the gel and directly sent for sequencing in both directions from Macrogen (Korea). Aligned sequences were deposited in the GenBank databases and their respective accession numbers were obtained (Table 1).

The sequencing results showed that the virus isolates belonged to 4 different begomovirus species. TYLCV-OM isolates were more prevalent on the squash crop while TOLCPMV isolates were detected on cucumber plants. On the other hand, one sample from cucumber was infected by WmCSV, which was the only detected virus in all watermelon plants and the most prevailing begomovirus detected from the cucurbits in Saudi Arabia (Soliman et al., 2018). All tomato samples were infected with TYLCV. TYLCV-OM was reported previously from Al-Batinah region in Oman (Khan et al., 2008). Data present in Fig. 3 and Table 2 reveals that all the begomovirus isolates from squash plants were 98 to $100 \%$ identical to each other while, shared their nt sequence identities 95 to $96 \%$ to the TYLCV-OM strain. The clone $\mathrm{Cu} 20$ from Cucumber were 98 to $100 \%$ nt sequence identity to other TYLCVOM from squash and showed 96\% nucleotide (nt) sequence identity to the TYLCV-OM strain reported from Oman. The clone To5 from tomato shared $98 \%$ identity to other TYLCV reported previously from Saudi Arabia and Kuwait and 95\% to TYLCV-OM strain. All TYLCV and TYLCV-OM were placed in group I, clade1 with identity ranged from 95 to $100 \%$, which indicated that TYLCV-OM strain was originated from TYLCV and jumped from solanaceous crops to cucurbits. International Committee on Taxonomy of Viruses (ICTV) has classified 
TYLCV-OM as an isolate of TYLCV from Iran. The group II in clade 1 includes all WmCSV isolates which shared identity with other reported WmCSV from Saudi Arabia and Palestine ranged from 97 to $99 \%$. The nt sequence identities between the begomovirus isolates from group I and group II were 71 to $76 \%$. The clade 2 includes all ToLCPMV isolates obtained from cucumber samples $\mathrm{Cu} 7$ and $\mathrm{Cu} 9$ which were $99 \%$ identical to Iranian isolates from cucumber and cantaloupe. These two isolates shared $94 \%$ identity with Indian isolates from musk melon, papaya, and also ToLCPMV obtained from tomato in Pakistan. ToLCPMV was first detected on tomato crops in India (Kumar et al., 2008) since then the virus has spread dramatically in cucurbit plants including melon and cucumber in Iran resulted in severe symptoms, which caused up to $100 \%$ losses in these two crops (Heydarnejad et al., 2009).

Global migration of begomviruses represents major threat to the vegetable
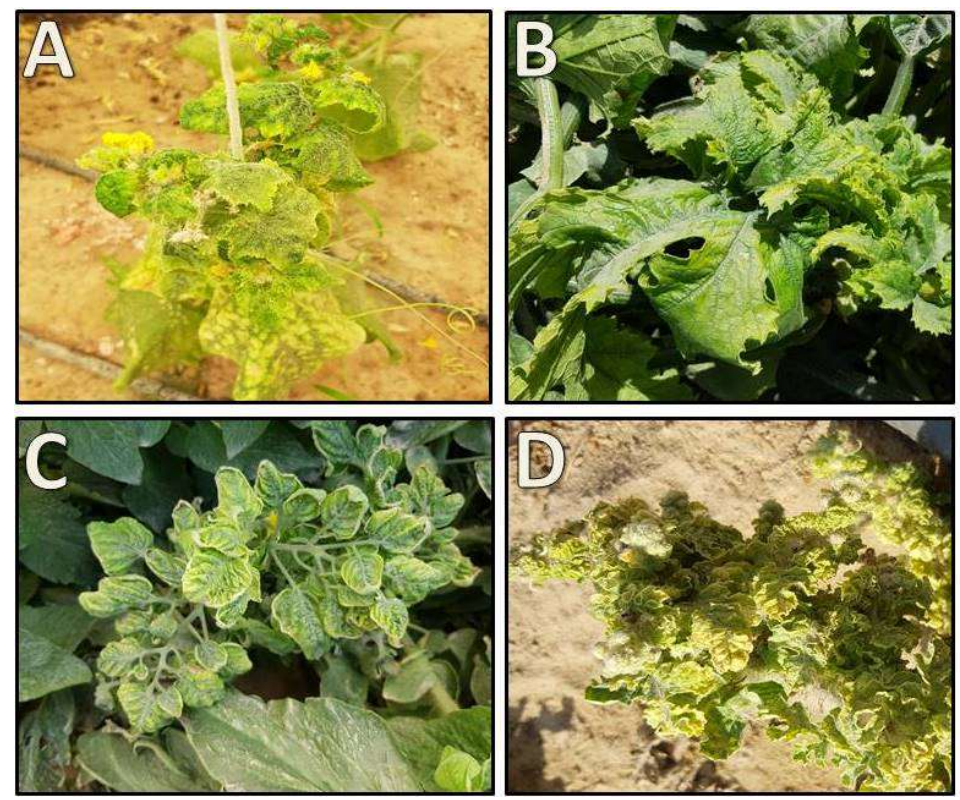

Fig. 1. Different symptoms of begomovirs infected plants. (A) Cucumber infected with Tomato leaf curl Palampur virus (ToLCPMV); (B) Squash infected with Tomato yellow leaf curl virus-Oman (TYLCV-OM); (C) Tomato infected with Tomato yellow leaf curl virus (TYLCV); and (D) Watermelon infected with Watermelon chlorotic stunt virus (WmCSV). production in the Middle Eastern countries. However, newly and more aggressive strains of begomoviruses may not be detected yet in Saudi Arabia. Extensive survey should be done to widen our knowledge about these newly emerging begomviruse species to protect vegetable production from these devastating viruses in Saudi Arabia.

\section{Conclusion}

Begomoviruses are major and serious threat to vegetable production under either open field or green houses-grown vegetable crops. New aggressive strains may be introduced to Saudi Arabia but not detected yet. ToLCPMV was detected only in India and Iran but not reported in the Arabian Peninsula. This requires further study to monitor these new introductions into the Saudi Arabia vegetable ecoysystem and to benefit from the study in the development of control strategies against begomvoriuses. 


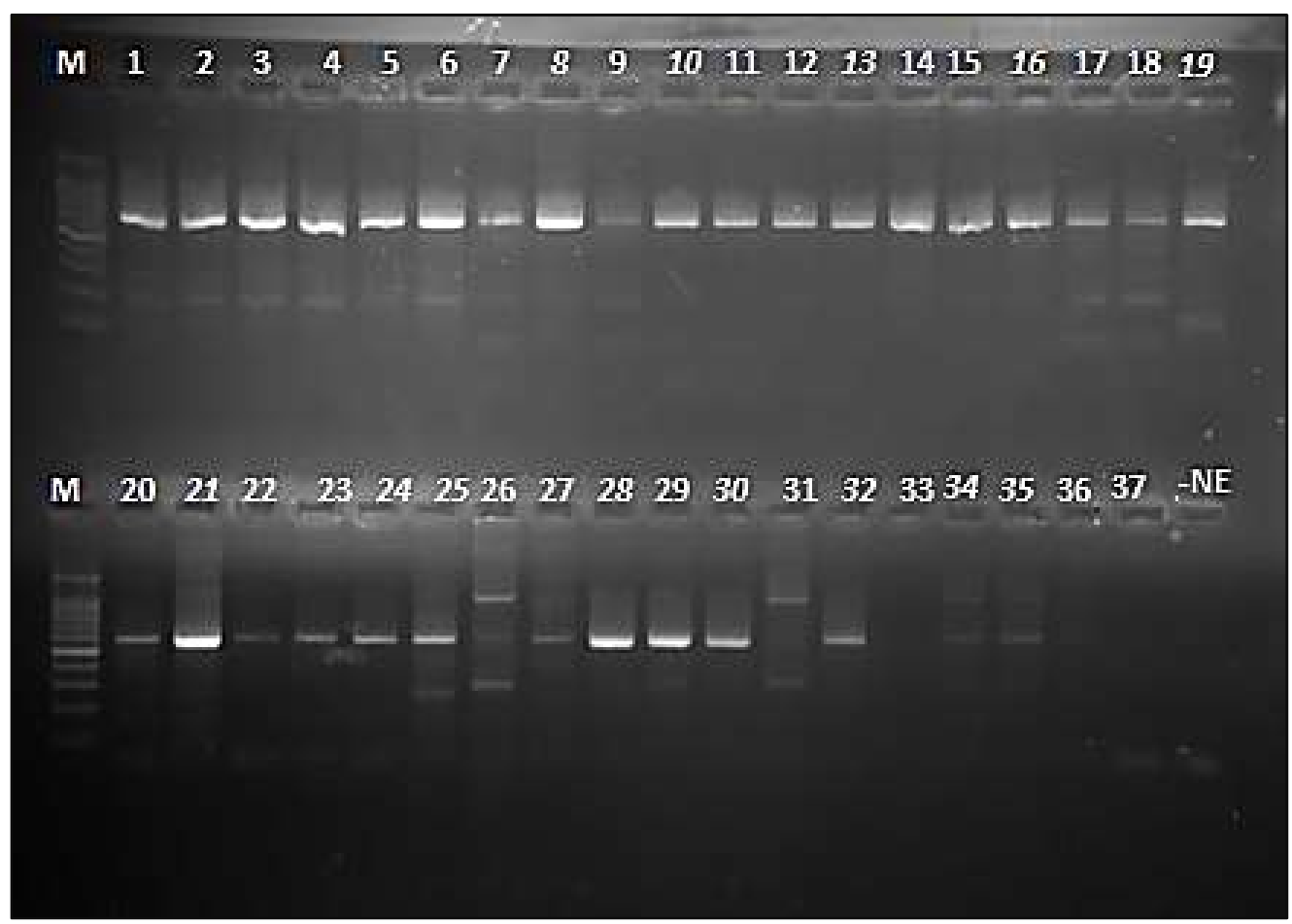

Fig. 2. PCR amplification of the core CP from the infected plant leaf samples in this study with AV494/ AC1048. . From lane 1-10 are cucumber samples, 11-20 are squash samples, 21- 30 are tomato samples while 31-37 are watermelon samples and $M$ is $100 \mathrm{bp}$ ladder. $-\mathrm{Ne}$ is non-template control.

Table 1. Deposited accession numbers of different begomviruses in this study.

\begin{tabular}{|c|c|c|c|c|c|}
\hline $\begin{array}{l}\text { Accession } \\
\text { number }\end{array}$ & $\begin{array}{l}\text { Isolate } \\
\text { name }\end{array}$ & Host & Virus name & Type & Acronym \\
\hline MG970132 & $\mathrm{Sq} 4$ & Squash & \multirow{9}{*}{$\begin{array}{l}\text { Tomato yellow leaf curl virus- } \\
\text { Oman }\end{array}$} & \multirow{9}{*}{ Monopartite } & \multirow{9}{*}{ TYLCV-OM } \\
\hline MG970133 & $\mathrm{Sq} 7$ & Squash & & & \\
\hline MG970134 & Sq8 & Squash & & & \\
\hline MG970135 & Sq9 & Squash & & & \\
\hline MG970136 & Sq10 & Squash & & & \\
\hline MG970137 & Sq12 & Squash & & & \\
\hline MG970138 & Sq13 & Squash & & & \\
\hline MG970139 & $\mathrm{Cu} 20$ & Cucumber & & & \\
\hline MG970140 & $\mathrm{Sq} 22$ & Squash & & & \\
\hline MH025640 & $\mathrm{Cu} 7$ & Cucumber & \multirow{2}{*}{ Tomato leaf curl Palampur virus } & \multirow{2}{*}{ Bipartite } & \multirow{2}{*}{ ToLCPMV } \\
\hline MH025641 & $\mathrm{Cu} 9$ & Cucumber & & & \\
\hline MH025643 & $\begin{array}{c}\mathrm{Cu} 1 \\
\mathrm{Wm} 1 \mathrm{O}\end{array}$ & Cucumber & Watermelon chlorotic stunt virus & Bipartite & WmCSV \\
\hline$\frac{\text { MH025644 }}{\text { MH025645 }}$ & $\frac{\text { Wm10 }}{\text { To5 }}$ & $\begin{array}{c}\text { Watermelon } \\
\text { Tomato }\end{array}$ & Tomato yellow leaf curl virus & Monopartite & TYLCV \\
\hline
\end{tabular}




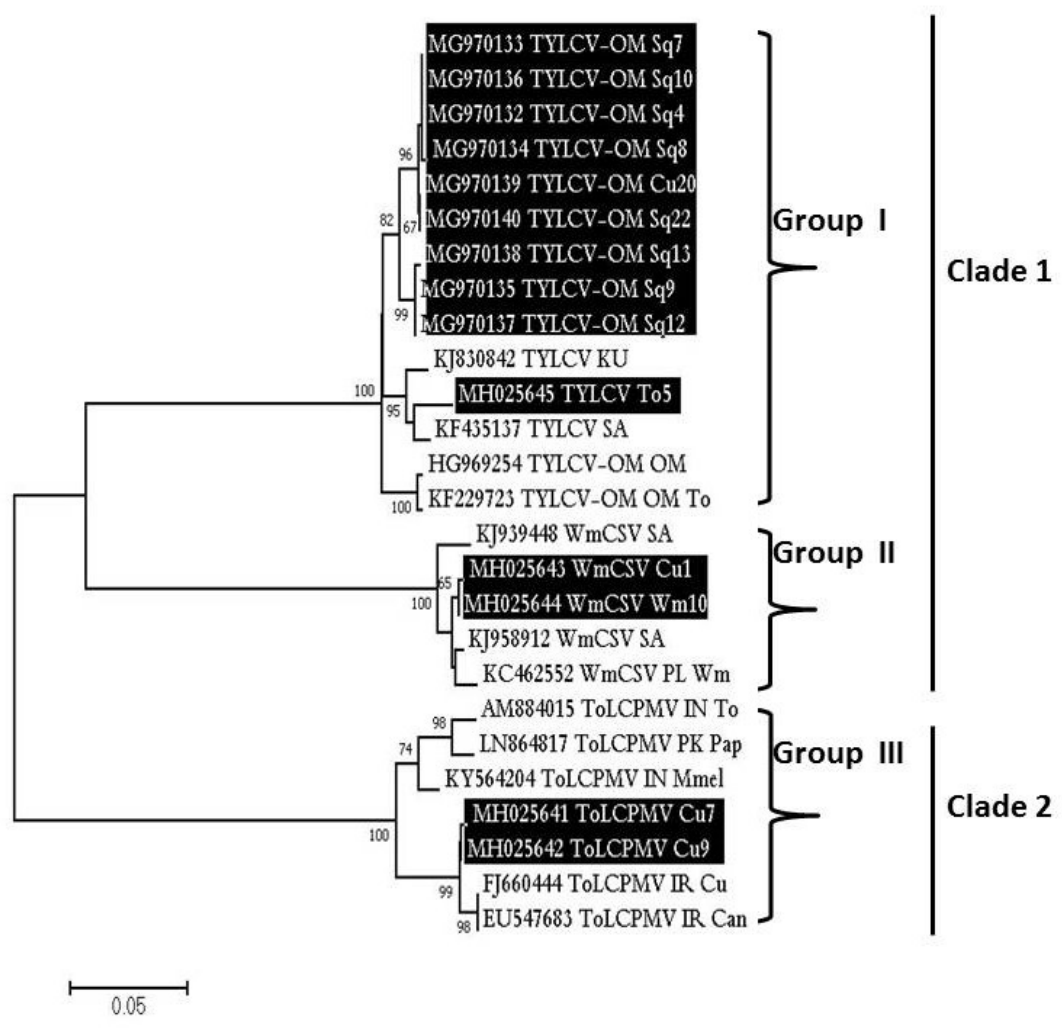

Fig. 3. Phylogenetic tree of evolutionary analyses between begomviruse isolates. Accession numbers obtained in this study are highlighted with white text on a black background.

Table 2. Pair-wise nucleotide sequence comparison 26 nucleotide sequences conducted in species demarcation tool (SDT).

\begin{tabular}{|c|c|c|c|c|c|c|c|c|c|c|c|c|c|c|c|c|c|c|c|c|c|c|c|c|c|c|}
\hline & 1 & 2 & 3 & 4 & 5 & 6 & 7 & 8 & 9 & 10 & 11 & 12 & 13 & 14 & \begin{tabular}{l|l}
15 & 1 \\
\end{tabular} & 16 & 17 & 18 & 19 & 202 & \begin{tabular}{|l|l}
21 & 2 \\
\end{tabular} & 22 & 23 & 24 & & 26 \\
\hline 1-MH025645_TYLCV_To5 & 100 & & & & & & & & & & & & & & & & & & & & & & & & & \\
\hline 2-KF435137_TYLCV_SA & 98 & 100 & & & & & & & & & & & & & & & & & & & & & & & & \\
\hline 3-HG969254_TYLCVOM_OM & 95 & 96 & 100 & & & & & & & & & & & & & & & & & & & & & & & \\
\hline 4-KF229723_TYLCVOM_OM_To & 95 & 96 & 99 & 100 & & & & & & & & & & & & & & & & & & & & & & \\
\hline 5-KJ830842_TYLCV_KU & 98 & 90 & 96 & 96 & 100 & & & & & & & & & & & & & & & & & & & & & \\
\hline 6-MG970135_TYLCVOM_Sq9 & 96 & 97 & 96 & 97 & 97 & 100 & & & & & & & & & & & & & & & & & & & & \\
\hline 7-MG970137_TYLCVOM_Sq12 & 96 & 97 & 96 & 97 & 97 & 100 & 100 & & & & & & & & & & & & & & & & & & & \\
\hline 8-MG970138_TYLCVOM_Sq13 & 96 & 97 & 96 & 96 & 97 & 100 & 100 & 100 & & & & & & & & & & & & & & & & & & \\
\hline 9-MG970139_TYLCVOM_Cu2O & 95 & 96 & 96 & 96 & 96 & 99 & 99 & 98 & 100 & & & & & & & & & & & & & & & & & \\
\hline 10-MG970140_TYLCVOM_Sq22 & 95 & 96 & 96 & 96 & 96 & 99 & 99 & 98 & 100 & 100 & & & & & & & & & & & & & & & & \\
\hline 11-MG970134_TYLCVOM_Sq8 & 95 & 96 & 96 & 97 & 96 & 98 & 98 & 98 & 100 & 100 & 100 & & & & & & & & & & & & & & & \\
\hline 12-MG970132_TYLCVOM_Sq4 & 95 & 96 & 96 & 97 & 96 & 98 & 98 & 98 & 100 & 100 & 100 & 100 & & & & & & & & & & & & & & \\
\hline 13-MG970133_TYLCVOM_Sq7 & 95 & 96 & 96 & 97 & 96 & 98 & 98 & 98 & 100 & 100 & 100 & 100 & 100 & & & & & & & & & & & & & \\
\hline 14-MG970136_TYLCVOM_Sq10 & 95 & 96 & 96 & 97 & 96 & 98 & 98 & 98 & 100 & 100 & 100 & 100 & 100 & 100 & & & & & & & & & & & & \\
\hline 15-MH025643_WmCSV_Cu1 & 74 & 75 & 76 & 76 & 76 & 76 & 76 & 76 & 75 & 75 & 76 & 76 & 76 & 76 & 100 & & & & & & & & & & & \\
\hline 16-KJ958912_WmCSV_SA & 75 & 71 & 77 & 76 & 72 & 76 & 76 & 76 & 75 & 75 & 76 & 76 & 76 & 76 & 99 & 100 & & & & & & & & & & \\
\hline 17-MH025644_WmCSV_Wm10 & 75 & 76 & 77 & 76 & 76 & 76 & 76 & 76 & 76 & 76 & 76 & 76 & 76 & 76 & 100 & 99 & 100 & & & & & & & & & \\
\hline 18-KC462552_WmCSV_PL_Wm & 74 & 71 & 76 & 76 & 71 & 75 & 75 & 76 & 75 & 75 & 75 & 75 & 75 & 75 & 98 & 98 & 98 & 100 & & & & & & & & \\
\hline 19-KJ939448_WmCSV_SA & 75 & 71 & 76 & 75 & 72 & 76 & 76 & 76 & 76 & 76 & 76 & 76 & 76 & 76 & 97 & 97 & 97 & 98 & 100 & & & & & & & \\
\hline 20-MH025641_ToLCPMV_Cu7 & 71 & 71 & 71 & 71 & 71 & 71 & 71 & 71 & 72 & 72 & 72 & 72 & 72 & 72 & 70 & 71 & 70 & 70 & 701 & 100 & & & & & & \\
\hline 21-MH025642_ToLCPMV_Cu9 & 71 & 71 & 71 & 71 & 71 & 71 & 71 & 71 & 72 & 72 & 72 & 72 & 72 & 72 & 707 & 71 & 70 & 72 & 701 & $100 \mid 1$ & 100 & & & & & \\
\hline 22-FJ660444_ToLCPMV_IR_Cu & 71 & 72 & 71 & 71 & 71 & 70 & 70 & 70 & 71 & 71 & 71 & 71 & 71 & 71 & 707 & 70 & 706 & 69 & $70 \mathrm{~s}$ & 99 & 99 & 100 & & & & \\
\hline 23-EU547683_ToLCPMV_IR_Can & 71 & 72 & 71 & 71 & 71 & 70 & 70 & 70 & 71 & 71 & 71 & 71 & 71 & 71 & 706 & 69 & 706 & \begin{tabular}{l|l}
69 & 7 \\
\end{tabular} & $70 \mathrm{~s}$ & 99 & 99 & 100 & 100 & & & \\
\hline 24-AM884015_ToLCPMV_IN_To & 72 & 72 & 71 & 71 & 72 & 71 & 71 & 70 & 71 & 71 & 71 & 71 & 71 & 71 & 717 & 70 & 706 & 69 & $70 \mathrm{~s}$ & 94 & 95 & 975 & 97 & 100 & & \\
\hline 25-LN864817_ToLCPMV_PK_Pap & 72 & 72 & 71 & 71 & 71 & 71 & 71 & 70 & 71 & 71 & 71 & 71 & 71 & 71 & 71 & 70 & 70 & 69 & 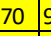 & 94 & 94 & 97 & 97 & \begin{tabular}{|l|llll}
99 & 1 & $r$
\end{tabular} & 100 & \\
\hline 26-KY564204_ToLCPMV_IN_Mmel & 73 & 72 & 72 & 72 & 73 & 72 & 72 & 72 & 72 & 72 & 72 & 73 & 73 & 73 & \begin{tabular}{l|l}
71 & 6 \\
\end{tabular} & 69 & 70 E 6 & \begin{tabular}{|l|l|ll}
69 & 6 \\
\end{tabular} & $69 \mathrm{~s}$ & 949 & $94 \quad 9$ & $93 \mathrm{~s}$ & \begin{tabular}{l|l}
93 & 9 \\
\end{tabular} & 94 & & 100 \\
\hline
\end{tabular}




\section{References}

Alhudaib, K. A., Rezk, A. A. S., Abdel-Banat, B. M. A. and Soliman, A. M. (2014). Molecular Identification of the Biotype of Whitefly (Bemisia tabaci) Inhabiting the Eastern Region of Saudi Arabia. Journal of Biological Sciences, 14 (8):494-500.

Al-Saleh, M. A., Ahmad, M. H., Al-Shahwan, I. M., Brown, J. K., and Idris, A. M. (2014). First report of Watermelon chlorotic stunt virus infecting watermelon in Saudi Arabia. Plant Disease, 98(10): 1451.

Doyle, J. J. (1987). A rapid DNA isolation procedure for small quantities of fresh leaf tissue. Phytochem Bull Bot Soc Am, 19: 11-15.

Ghanem, G. A. M., Al-Ajlan, A. M. and Abdulsalam, K. S. (2003). A whitefly-transmitted geminivirus infecting bean (Phaseolus vulgaris L.) plants in Saudi Arabia. Egyptian Journal of Phytopathology, 31: 1-15.

Gilbertson, R. L., Batuman, O., Webster, C. G. and Adkins, S. (2015). Role of the insect supervectors Bemisia tabaci and Frankliniella occidentalis in the emergence and global spread of plant viruses. Annual Review of Virology, 2: 67-93.

Heydarnejad, J., Mozaffari, A., Massumi, H., Fazeli, R., Gray, A. J., Meredith, S. and Varsani, A. (2009). Complete sequences of tomato leaf curl Palampur virus isolates infecting cucurbits in Iran. Archives of Virology, 154 (6): 1015-1018.

Khan, A. J., Idris, A. M., Al-Saady, N. A., Al-Mahruki, M. S., Al-Subhi, A. M. and Brown, J. K. (2008). A divergent isolate of Tomato yellow leaf curl virus from Oman with an associated DNA $\beta$ satellite: an evolutionary link between Asian and the Middle Eastern virus-satellite complexes. Virus Genes, 36 (1): 169-176.

Kimura M. (1980). A simple method for estimating evolutionary rate of base substitutions through comparative studies of nucleotide sequences. Journal of Molecular Evolution, 16: 111-120.
Kumar, Y., Hallan, V. and Zaidi, A. A. (2008). Molecular characterization of a distinct bipartite begomovirus species infecting tomato in India. Virus Genes, 37 (3): 425-431.

Kumar S., Stecher G. and Tamura K. (2016). MEGA7: Molecular Evolutionary Genetics Analysis version 7.0 for bigger datasets. Molecular Biology and Evolution, 33: 1870-1874.

Muhire, B.M., Varsani, A. and Martin, D.P. (2014). SDT: A Virus Classification Tool Based on Pairwise Sequence Alignment and Identity Calculation. PLOS ONE, 9.

Sohrab, S. S. (2017). Association of Tomato leaf curl Sudan virus with leaf curl disease of Squash in Saudi Arabia. Agrica, 6 (1): 28-34.

Sohrab, S. S., Yasir, M. and El-Kafrawy, S. A. (2017). Begomovirus infection on Cucumber in Saudi Arabia. Plant Omics, 10 (1): 7.

Soliman, A. M., Rezk, A. A. and Alhudaib, K. A. (2018). Cucurbit yellow stunting disorder virus and watermelon chlorotic stunt virus induced gene silencing in tobacco plants. African Journal of Biotechnology, 17 (7): 189-197.

Talhouk, A. M. S. (1957). Diseases and Insect Pests of Crops in the Eastern Province of Saudi Arabia. Published by Arabian American oil company, Dammam, 87pp.

Wyatt, S. D. and Brown, J. K. (1996). Detection of subgroup III geminivirus isolates in leaf extracts by degenerate primers and polymerase chain reaction. Phytopathology, 86 (12): 1288-1293.

Zerbini, F. M., Briddon, R. W., Idris, A., Martin, D. P., Moriones, E., Navas-Castillo, J. and Varsani, A. (2017). ICTV virus taxonomy profile: geminiviridae. Journal of General Virology, 98 (2): 131-133.

Zhou, X. (2013). Advances in understanding begomovirus satellites. Annual review of phytopathology, 51: 357-381. 

الكثف الجزيئي لفيروسات البيجمو التي تصيب بعض محاصيل الخضر في المملكة العربية السعودية

\author{
خالد الإضيب \\ جامعة الملك فبصل، الأحساء، المملكة العربية السعودية
}

kalhudaib@kfu.edu.sa

المستخلص. فيروسات البيجمو لها تأثير كبير على إنتاج المحاصيل في جميع أنحاء العالم. تم

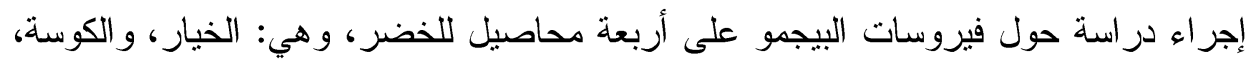
و الطماطم، والبطيخ، عن طريق الأعراض الظاهرية و التحليل الجزيئي باستخدام تفاعل البلمرة ولئه

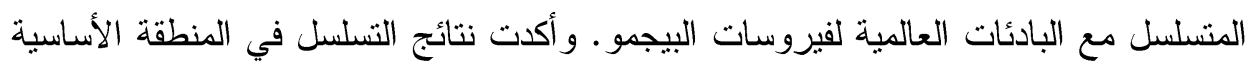
في الجين الذي يشفر للغلاف البروتيني وجود ثلاثة أنواع من فيروسات البيجمو، والتي نم

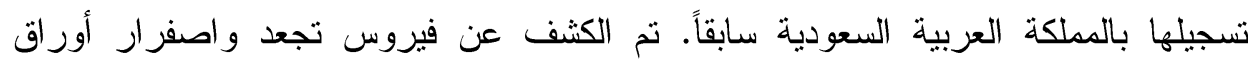

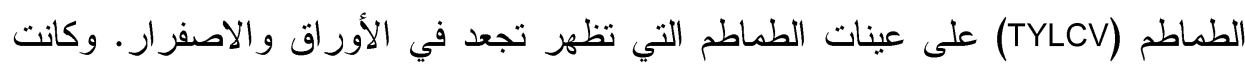

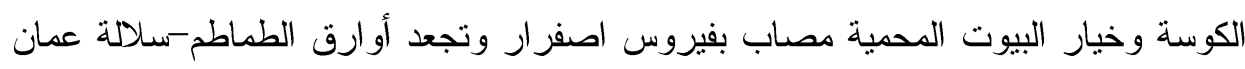
(TYLCV-OM) في البطيخ (WmCSV). وكانت عزلات فيروس تجعد أوراق الطماطح بالامبور تتطابق بنسبة

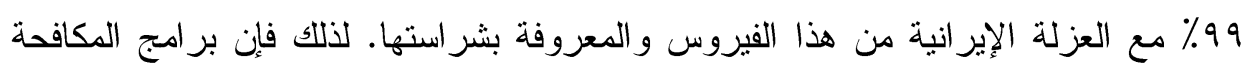
المتكاملة يجب تطبيقها ضد الذبابة البيضاء لمنع انتشار فيروسات البيجمو على محاصيل الخضر.

الكلمات الدفتاحية: فيروسات البيجمو، الخيار، كوسة، طماطم، بطيخ، تفاعل البلمرة المتسلسل، السعودية. 